\title{
Response of Butternut Selections to Inoculation with Sirococcus clavigignenti-juglandacearum
}

\author{
M. E. Ostry and M. Moore, Northern Research Station, St. Paul, MN 55108
}

\begin{abstract}
Ostry, M. E., and Moore, M. 2008. Response of butternut selections to inoculation with Sirococcus clavigignenti-juglandacearum. Plant Dis. 92:1336-1338.

Butternut trees (Juglans cinerea) clonally propagated via grafting from source trees with putative resistance to butternut canker were inoculated monthly with two isolates of Sirococcus clavigignenti-juglandacearum in a field planting in Minnesota. Significant differences in resulting canker length were found among (i) month of inoculation, (ii) accession, and (iii) isolate. Results support the suggestion that canker-free butternut occasionally found growing among butternut severely affected by butternut canker potentially have disease resistance and may have value for genetic conservation and restoration of the species. Developing an effective resistance screening technique will require additional information on the natural infection process and testing under various climatic conditions across the range of butternut.
\end{abstract}

Additional keywords: disease resistance screening

Sirococcus clavigignenti-juglandacearum, described in 1979 (5), is killing butternut (Juglans cinerea) throughout North America and is threatening the survival of the species in many parts of its native range (11). The relatively rapid increase in the incidence of the canker disease since its discovery has been attributed to dissemination of conidia by rain splash, aerosols (14), and insects $(3,13)$. The fungus can also be seedborne on butternut and black walnut (J. nigra) (2) and can fruit on dead trees for nearly 2 years (15). In artificial inoculations of greenhouse-grown plants, the pathogen was able to colonize several genera of hardwoods in addition to butternut, and several commercially important Persian walnut (J. regia) cultivars were moderately or highly susceptible (9).

Butternut, although never commercially important for timber or nut production, is an ecologically important species in eastern hardwood forests. Scarcity of large trees resulting from tree mortality predominately caused by butternut canker has increased the value of the wood, highly prized for woodworking, and has reduced the availability of an important mast species to wildlife (10). In addition, eating butternuts has human health benefits (4), and butternut bark extracts may have value

Corresponding author: M. E. Ostry

E-mail mostry@fs.fed.us

Accepted for publication 8 June 2008.

doi:10.1094/PDIS-92-9-1336

This article is in the public domain and not copyrightable. It may be freely reprinted with customary crediting of the source. The American Phytopathological Society, 2008. for their high level of antibiotics (6), including some that inhibit humanpathogenic fungi (1).

Concern over the loss of butternut has motivated investigators in the United States and Canada to examine the potential conservation of individual trees that may have resistance to the disease (12). Occasionally, one to several healthy butternut trees are found growing among groups of similarly aged diseased and dying butternut, and it has been speculated that these trees may have resistance to the disease and this germplasm may have value for future conservation and restoration of the species (11).

Few experimental investigations have been made to determine the level of canker resistance among butternut populations or individual trees; however, evidence sug- gests that some trees may be resistant $(7,8)$. However, no controlled inoculations of sapling-sized, clonally propagated butternut trees have been undertaken and knowledge of the effect of season on inoculation success and disease development is lacking. Results from previous inoculations of grafted, field-grown butternut accessions from healthy and diseased source trees at various times during the growing season were ambiguous (unpublished data).

The objectives of this study were to (i) examine the influence of month of inoculation on infection and (ii) test the hypothesis that selected butternut trees have more resistance to butternut canker than unselected trees.

\section{MATERIALS AND METHODS}

Butternut selections. Beginning in spring 2003, 43 grafted 7- to 11-year-old trees propagated from 15 healthy, mature source trees ( 2 to 3 trees from each accession; Table 1) in a plantation near Rosemount, MN were tested for canker resistance. Also tested were six trees of 9-yearold, seedgrown butternut from unknown source trees. Tree heights ranged from 1.8 to $7.8 \mathrm{~m}$, with a mean of $3.3 \mathrm{~m}$.

Source trees were selected from 1990 to 1996 in various locations within the natural range of butternut. The source trees were over $25 \mathrm{~cm}$ in diameter and growing among severely diseased and killed butternut. In fall 2003, an examination of source trees revealed that three of the trees had developed one or more stem or branch cankers.

Table 1. Juglans cinerea source trees and canker prevalence

\begin{tabular}{lll}
\hline Accession (no.) $^{\mathbf{x}}$ & \multicolumn{1}{c}{ Location } & Canker prevalence \\
\hline $1(3)$ & Dunn Co., WI & No cankers \\
$13(3)$ & Olmstead Co., MN & Branch and stem cankers \\
$17(3)$ & Olmstead Co., MN & Branch cankers only \\
$19(3)$ & Olmstead Co., MN & Callused-over stem canker \\
$20(3)$ & Rock Co., WI & No cankers \\
$22(3)$ & Rock Co., WI & No cankers \\
$23(3)$ & Rock Co., WI & No cankers \\
$54(3)$ & Forest Co., WI & No cankers \\
$60(2)$ & Rock Co., WI & No cankers \\
$67(2)$ & Rice Co., MN & No cankers \\
$86(3)$ & Pulaski Co., MO & No cankers \\
$146(3)$ & Rock Co., WI & No cankers \\
$148(3)$ & Rock Co., WI & No cankers \\
$174(3)$ & Marinette Co., WI & No cankers \\
$181(3)$ & Menominee Co., MI & No cankers \\
$200(6)^{\mathrm{z}}$ & Unknown & Unknown \\
\hline
\end{tabular}

${ }^{x}$ Number of trees inoculated shown in parentheses.

y Cankers first noted in 2003.

${ }^{\mathrm{z}}$ Open-pollinated seed origin. 
Origin of isolates and inoculum preparation. Inoculum was prepared from sporulating 2- to 3 month-old cultures of $S$. clavigignenti-juglandacearum grown on malt agar at $20^{\circ} \mathrm{C}$ in the dark. Isolates used were WI1344 and MN1347, cultured from butternut cankers on branches collected from Forest County, WI and Kanabec County, MN, respectively. A $40-\mathrm{mm}^{2}$ section of each culture was ground separately with a sterile mortar and pestle, mixed with $10 \mathrm{ml}$ of sterile water, and placed in a sterile dropper bottle.

Inoculations. We inoculated branches to assess monthly differences in susceptibility of individual trees without sacrificing the trees by inoculating their main stems. Each month, beginning in April and continuing through October, individual third-year branches (a different branch each month) ranging in diameter from 9 to $26 \mathrm{~mm}$ on each tree were wounded using a cordless electric drill with a 7-mm forstner bit to make three wounds 10 to $15 \mathrm{~cm}$ apart through the bark to the cambium. Third-year wood was inoculated because this is the age of wood on which we most often find incipient cankers in the upper crowns of trees. Each branch wound received one of three treatments. Two of the wounds were inoculated with a $50-\mu l$ drop of one or the other of the two $S$. clavigignenti-juglandacearum isolates; the third wound was inoculated with sterile media slurry that served as a control. Each wound was wrapped in a laboratory film that was removed after the first examination 1 month later.

Canker evaluations and statistical analyses. Canker lengths were recorded monthly through October and final measurements were made in June 2004 based on visual canker symptoms in the field. In July, inoculated branches were brought into the laboratory where the bark was removed from wound sites to compare canker lengths under the bark with those

Table 2. Canker incidence by month of inoculation of Juglans cinerea with Sirococcus clavigignenti-juglandacearum April 2003 to October $2003^{\mathrm{w}}$

\begin{tabular}{lcc}
\hline $\begin{array}{l}\text { Inoculation } \\
\text { month }\end{array}$ & $\begin{array}{c}\text { Branches } \\
(\text { (no. })^{\mathbf{x}}\end{array}$ & $\begin{array}{c}\text { Cankered } \\
(\boldsymbol{\%})^{\mathbf{y}}\end{array}$ \\
\hline May & 76 & $64 \mathrm{a}$ \\
June & 78 & $71 \mathrm{a}$ \\
April & 70 & $79 \mathrm{ab}$ \\
August & 82 & $89 \mathrm{~b}$ \\
July & 84 & $92 \mathrm{~b}$ \\
September $^{\mathrm{z}}$ & 88 & 100 \\
October $^{\mathrm{z}}$ & 88 & 100 \\
\hline
\end{tabular}

${ }^{\text {w }}$ Data collected June 2004. Combined data using 2 isolates and $16 \mathrm{~J}$. cinerea accessions.

${ }^{x}$ Number of branches varies due to death or damage during study.

y Values with the same letter do not differ significantly according to Tukey-Kramer's least squares means test $(P=0.05)$.

${ }^{\mathrm{z}}$ Months with $100 \%$ incidence not included in the statistical analysis. measured in the field. Tissue samples were removed from selected canker margins and plated on potato dextrose agar maintained at $20^{\circ} \mathrm{C}$ in the dark for pathogen confirmation.

None of the control inoculations resulted in canker development and they were removed from the analysis. No isolate-accession interaction was detected and data from inoculations with both isolates were combined. Because the response variables were from the exponential distribution family, data were analyzed using a maximum likelihood estimation technique via PROC GLIMMIX (version 9.0; SAS Institute, Cary, NC). Two separate analyses were run.

In the first analysis, we tested the likelihood of canker development. Because cankers always developed in September and October, these inoculation months were excluded from this analysis. For this analysis, we used a binary distribution with a logit link function. Isolate, inoculation month, tree accession, and replication were fixed effects in the model. Least squares means separation tests for fixed effects were conducted using a TukeyKramer procedure.

In the second analysis, we examined the length of cankers that developed. In this analysis, only treatment combinations that produced cankers were used. For this analysis, we used a negative binomial distribution and a log link function. Isolate, inoculation month, tree accession, and replication were fixed effects in the model. Least squares means separation tests for fixed effects were conducted using a Tukey-Kramer procedure.

\section{RESULTS}

Both isolates were pathogenic but canker incidence and canker lengths were significantly $(P<0.001)$ greater after 8 to 14 months when trees of all accessions were inoculated with isolate WI1344 than with isolate MN1347. Canker length measurements in the field based on bark collapse and discoloration were similar to measurements taken with the bark removed in the laboratory (data not shown). S. clavigignenti-juglandacearum was re- covered in pure culture from canker margins on selected symptomatic branches inoculated with each isolate.

Month of inoculation significantly $(P=$ 0.05) influenced canker incidence and canker lengths (Tables 2 and 3). Cankers always developed on trees regardless of accession when inoculated in September and October and the largest cankers developed with no significant differences among accessions during those months with either isolate.

All accessions were susceptible to $S$. clavigignenti-juglandacearum to varying degrees, but significant differences $(P<$ $0.001)$ were found among accessions in canker incidence and canker length (Tables 4 and 5). Trees of accession 67 developed significantly $(P<0.001)$ fewer cankers than the other accessions when inoculated during the growing season (Table 4); however, the resulting canker lengths on this accession were among the accessions with the largest cankers (Table 5).

\section{DISCUSSION}

This study demonstrated that all of the trees propagated from canker-free source trees were susceptible to infection by $S$. clavigignenti-juglandacearum when artificially inoculated through wounds. The relatively large wounds and large amount of inoculum used may have overcome resistant mechanisms effective for natural inoculations. Canker elongation after wound inoculation may demonstrate variation in the fungus isolate virulence but is not related to resistance to infection. However, detection of differences in disease severity among some of the accessions is encouraging. Results support the suggestion that canker-free trees occasionally present within populations of butternut severely affected by butternut canker may be more resistant than nearby diseased trees. Similar to the results of Orchard (8), the most rapid expansion of branch cankers occurred in the spring as the result of fall inoculations, and levels of disease resistance among trees was expressed as differences in canker lengths. As of 2007, source trees used in this study were still apparently healthy, except for the three

Table 3. Canker length by month of inoculation of Juglans cinerea with Sirococcus clavigignentijuglandacearum April 2003 to October $2003^{\mathrm{x}}$

\begin{tabular}{lcccc}
\hline & & \multicolumn{3}{c}{${\text { Canker length }(\mathbf{m m})^{\mathbf{y}}}$} \\
\cline { 3 - 5 } Inoculation month & Branches (no.) $^{\mathbf{z}}$ & Mean & Range & SE \\
\hline August & 82 & $29 \mathrm{a}$ & $2-211$ & 5.63 \\
May & 76 & $42 \mathrm{~b}$ & $5-193$ & 5.74 \\
June & 78 & $48 \mathrm{bc}$ & $4-181$ & 5.81 \\
July & 84 & $61 \mathrm{bc}$ & $3-297$ & 7.70 \\
April & 70 & $71 \mathrm{~cd}$ & $7-150$ & 6.32 \\
September & 88 & $109 \mathrm{de}$ & $5-225$ & 6.38 \\
October & 88 & $115 \mathrm{e}$ & $13-213$ & 4.21 \\
\hline
\end{tabular}

${ }^{x}$ Data collected June 2004. Combined data using 2 isolates and 16 J. cinerea accessions.

y Only branches that developed cankers were included. Values with the same letter do not differ significantly according to Tukey-Kramer's least squares means test $(P=0.05)$; $\mathrm{SE}=$ standard error.

${ }^{\mathrm{z}}$ Number of branches varies due to death or damage during study. 
Table 4. Incidence of canker on Juglans cinerea accessions inoculated with Sirococcus clavigignenti-juglandacearum April 2003 to August $2003^{\mathrm{w}}$

\begin{tabular}{lcc}
\hline Accession & $\begin{array}{c}\text { Branches } \\
(\text { (no.) }\end{array}$ & $\begin{array}{c}\text { Cankered } \\
(\boldsymbol{\%})^{\mathbf{x}}\end{array}$ \\
\hline 67 & 28 & $20 \mathrm{a}$ \\
54 & 42 & $57 \mathrm{ab}$ \\
60 & 28 & $65 \mathrm{ab}$ \\
1 & 42 & $73 \mathrm{ab}$ \\
23 & 30 & $75 \mathrm{ab}$ \\
86 & 34 & $77 \mathrm{ab}$ \\
148 & 42 & $77 \mathrm{ab}$ \\
17 & 20 & $83 \mathrm{ab}$ \\
22 & 36 & $83 \mathrm{~b}$ \\
181 & 30 & $86 \mathrm{~b}$ \\
$200^{\mathrm{y}}$ & 76 & $87 \mathrm{~b}$ \\
146 & 42 & $90 \mathrm{~b}$ \\
174 & 34 & $95 \mathrm{~b}$ \\
$13^{\mathrm{z}}$ & 28 & 100 \\
$19^{\mathrm{z}}$ & 34 & 100 \\
$20^{\mathrm{z}}$ & 20 & 100 \\
\hline
\end{tabular}

${ }^{\mathrm{w}}$ Data collected in June 2004. Combined data using two isolates.

${ }^{x}$ Data from months with $100 \%$ infection (September and October) were removed from analysis. Values with the same letter do not differ significantly according to TukeyKramer's least squares means test $(P=0.05)$.

y Open pollinated, unknown seed origin.

${ }^{\mathrm{z}}$ Tree lines with $100 \%$ incidence were not included in the analysis.

trees that have a few nonlethal stem or branch cankers, despite a high incidence of mortality of adjacent trees caused by butternut canker. One tree has not been reexamined since it was selected and its current health status is unknown.

Although a difference in virulence among the two isolates was detected, choice of isolate did not appreciably affect the results. However, because month of inoculation significantly affected canker incidence and severity, preliminary resistance testing under various climatic conditions and growing seasons across the range of butternut may be warranted before widespread disease resistance screening is carried out. Additional information on the natural infection process and entry courts is also needed in order to develop an inoculation technique that relies on a less severe wound that will not mask potential resistance mechanisms. A conservative screening to determine maximum butternut canker resistance using the technique described in this article may best be done with a highly virulent isolate in the fall when susceptibility and canker development was greatest.

\section{ACKNOWLEDGMENTS}

We thank J. Rowe, J. Karelis, and K. Karelis, University of Minnesota Agriculture Experiment

Table 5. Canker length on Juglans cinerea accessions inoculated with Sirococcus clavigignentijuglandacearum April 2003 to October $2003^{\mathrm{x}}$

\begin{tabular}{lcccr}
\hline & & \multicolumn{3}{c}{${\text { Canker length }(\mathbf{m m})^{\mathbf{y}}}$} \\
\cline { 3 - 5 } Accession & Branches (no.) & Mean & Range & SE \\
\hline 22 & 36 & $49 \mathrm{a}$ & $5-144$ & 7.63 \\
1 & 42 & $53 \mathrm{a}$ & $3-123$ & 7.60 \\
148 & 42 & $56 \mathrm{a}$ & $4-178$ & 9.13 \\
60 & 28 & $51 \mathrm{ab}$ & $4-117$ & 9.02 \\
13 & 28 & $53 \mathrm{ab}$ & $4-167$ & 10.35 \\
54 & 42 & $69 \mathrm{ab}$ & $2-213$ & 13.02 \\
146 & 42 & $62 \mathrm{abc}$ & $4-213$ & 8.54 \\
19 & 34 & $62 \mathrm{abc}$ & $6-146$ & 7.88 \\
23 & 30 & $65 \mathrm{abc}$ & $3-205$ & 13.60 \\
181 & 30 & $66 \mathrm{abc}$ & $6-157$ & 10.80 \\
20 & 20 & $71 \mathrm{abc}$ & $6-155$ & 10.54 \\
17 & 20 & $83 \mathrm{abc}$ & $7-181$ & 13.06 \\
174 & 34 & $87 \mathrm{abc}$ & $4-225$ & 12.37 \\
67 & 28 & $108 \mathrm{abc}$ & $6-193$ & 17.57 \\
86 & 34 & $106 \mathrm{bc}$ & $5-183$ & 12.87 \\
$200^{\mathrm{z}}$ & 76 & $105 \mathrm{c}$ & $5-297$ & 7.77 \\
\hline
\end{tabular}

${ }^{x}$ Data collected in June 2004. Combined data using two isolates.

${ }^{y}$ Only branches that developed cankers included. Values with the same letter do not differ significantly according to Tukey-Kramer's least squares means test $(P=0.05)$; $\mathrm{SE}=$ standard error.

${ }^{\mathrm{z}}$ Open pollinated, unknown seed origin.

Station, for field plot assistance; and J. Stanovick for statistical advice in this study.

\section{LITERATURE CITED}

1. Ficker, C. E., Arnason, J. T., Vindas, P. S., Alvarez, L. P., Akpangana, K., Gbéassor, De Souza, C., and Smith, M. L. 2003. Inhibition of human pathogenic fungi by ethnobotanically selected plant extracts. Mycoses 46:2937.

2. Innes, L. 1997. Sirococcus clavigignentijuglandacearum on butternut and black walnut fruit. Pages 129-132 in: Foliage, Shoot and Stem Diseases of Trees: Proc. IUFRO WP 7.02.02 Meeting. G. Laflamme, J. A. Bérubé, and R. C. Hamelin, eds. Natural Resources Canada, Canadian Forest Service, Laurentian Forestry Centre, Quebec City, Quebec, Canada.

3. Katovich, S. A., and Ostry, M. E. 1998. Insects associated with butternut and butternut canker in Minnesota and Wisconsin. Great Lakes Entomol. 31:97-108.

4. Krochmal, A., and Krochmal, C. 1982. Genus Juglans L. Walnut. Pages 51-58 in: Uncultivated Nuts of the United States. Agric. Inf. Bull. 450. U. S. Dep. Agric. For. Serv. Washington, DC

5. Nair, V. M. G., Kostichka, C. J., and Kuntz, J. E. 1979. Sirococcus clavigignenti-juglandacearum: an undescribed species causing canker on butternut. Mycologia 71:641-646.

6. Omar, S., Lemonnier, B., Jones, N., Ficker, C., Smith, M. L., Neema, C., Towers, G. H. N., Goel, K., and Arnason, J. T. 2000. Antimicrobial activity of extracts of eastern North American hardwood trees and relation to traditional medicine. J. Ethnopharmacol. 73:161170.

7. Orchard, L. P., Guries, R. P., and Kuntz, J. E. 1981. Butternut canker: screening seedlings for disease resistance. (Abstr.) Phytopathology $71: 247$

8. Orchard, L. P., Kuntz, J. E., and Kessler, K. J. 1982. Reactions of Juglans species to butternut canker and implications for disease resistance. Pages 27-31 in: Black Walnut for the Future: Gen. Tech. Rep. NC-74. U.S. Dep. Agric. For. Serv. N. Cent. For. Exp. Stn. St. Paul, MN.

9. Ostry, M. E., and Moore, M. 2007. Natural and experimental host range of Sirococcus clavigignenti-juglandacearum. Plant Dis. 91:581584.

10. Ostry, M. E., and Pijut, P. M. 2000. Butternut: an underused resource in North America. HortTechnology 10:302-306.

11. Ostry, M. E., and Woeste, K. 2004. Spread of butternut canker in North America, host range, evidence of resistance within butternut populations and conservation genetics. Pages 114-120 in: Black Walnut in a New Century. Proc. 6th Walnut Council Res. Symp. Lafayette, IN. C. H. Michler, P. M. Pijut, J. Van Sambeek, M. Coggeshall, J. Seifert, K. Woeste, and R. Overton, eds. Gen. Tech. Rep. NC-243. U. S. Dep. Agric. For. Serv. N. Cent. Res. Stn. St. Paul, MN.

12. Schlarbaum, S. E., Anderson, R. L., Ostry, M. E., Brosi, S. L., Thompson, L. M., Clark, S. L., van Manen, F. T., Spaine, P. C., Young, C., Anagnostakis, S. A., and Brantley, E. A. 2004. An integrated approach for restoring butternut to Eastern North American forests. Pages 156158 in: Forest Genetics and Tree Breeding in the Age of Genomics: Progress and Future. L. Bailian and S. McKeand, eds. Proc. Joint Conf. IUFRO Div. 2, Charleston, SC

13. Stewart, J. E., Halik, S., and Bergdahl, D. R. 2004. Viability of Sirococcus clavigignentijuglandacearum conidia on exoskeletons of three Coleopteran species. Plant Dis. 88:10851091.

14. Tisserat, N., and Kuntz, J. E. 1983. Dispersal gradients of conidia of the butternut canker fungus in a forest during rain. Can. J. For. Res. 13:1139-1144.

15. Tisserat, N., and Kuntz, J. E. 1984. Butternut canker: Development on individual trees and increase within a plantation. Plant Dis. 68:613616. 